\title{
NOTES
}

\section{INSURANCE LIQUIDATIONS: A PROPOSED AMENDMENT TO THE MCCARRAN-FERGUSON ACT}

THE assets of insolvent multi-state insurance corporations are neither uniformly nor equitably distributed under the existing system of state liquidation. ${ }^{1}$ Divergent state views on the status of foreign receivers have defeated the proper aim of insurance liquidations-equitable distribution of assets among all policyholders and creditors with a minimum of waste and expense." Formerly, all states applied the rule that an equity receiver did not have title to an insolvent's assets. ${ }^{3}$ He was therefore without standing to sue or be sued outside the jurisdiction appointing him, and foreign states would recognize him as a matter of comity only when recognition did not adversely affect local interests. ${ }^{4}$ To avoid this rule, many states enacted laws creating "statutory" receivers who would take legal title to the insolvent's assets. . And though in 1934 the Supreme Court held that no state could dishonor the title of a foreign statutory receiver, ${ }^{6}$ it one year later upheld the constitutionality of state policy

1. "The existing system of liquidating insolvent insurance corporations doing business in many states is intolerable in its inefficiency, its expensiveness, its delays and its injustice."

Vance, Interstate Aspects of the Liquidation of Insolvent Insurance Corporations, 6 Association of Life Insurance Counsel Proceedings 343, 354 (1935). See also Van Schaick, Should Insolvent Interstate Insurance Companies Be Administered in Bankruptcy?, A2 Corporate Reorganizations 227 (1939).

2. See Pensinger v. Pacific States Life Ins. Co., 25 F. Supp. 295, 297 (E.D. Mo. 1938); Motlow v. Southern Holding \& Securities Corp., 95 F.2d 721, 724 (Sth Cir. 1938) ; GLEN, Liquidation \& 3 (1935).

As used in this Note "foreign" refers to other jurisdictions within the United States and "alien" denotes jurisdictions outside the United States. For a discussion of the problems in liquidating insolvent alien insurance corporations doing business within the United States, see Bennett, Liquidation of Insurance Companies, 4 ExarINation of Insurance Companies 416-18 (1954).

3. Great Western Mining and Mfg. Co. v. Harris, 198 U.S. 561 (1905); Security Trust Co. v. Dodd, Mead \& Co., 173 U.S. 624 (1899); Humphreys v. Hopkins, 81 Cal. 551, 22 Pac. 892 (1889).

4. Booth v. Clark, 58 U.S. (17 How.) 321 (1855) ; Hurd v. Elizabeth, 41 N.J.L. 1 (1879); Gilman v. Ketcham, 84 Wis. 60, 54 N.W. 395 (1893). See also Boulware v. Davis, 90 Ala. 207, 8 So. 84 (1890). But see Security Trust Co. v. Dodd, Mead \& Co., supra note 3 (non-resident creditor recognized ahead of foreign receiver).

5. The statutory receiver is usually the State Superintendent of Insurance or his equivalent. See, e.g., Conn. Gen. Stat. $\$ 6037$ (Supp. 1955); Minn. Stat. Ann. $\$ 60.875$, pt. 18 (Supp. 1956) ; Mo. Ann. Stat. $\$ 375.650$ (Supp. 1956) ; PA. Stat. AnN. tit. 40, $\$ 206$ (Purdon Supp. 1956). For discussion of these statutes, see People cr. rel. Jones v. Chicago Lloyds, 391 Ill. 492, 496-99, 63 N.E.2d 479, 483 (1945).

6. Clark v. Williard, 292 U.S. 112 (1934). The Court made clear that foreign liquida- 
subordinating his claims to attachments by local creditors. ${ }^{7}$ Protected by the latter decision, many states postpone recognition of a foreign receiver's claims until all claims of local creditors have been satisfied. ${ }^{8}$ Thus the amount a given creditor will receive depends on the extent of local assets and the number

tors vested by statute with legal title could not be deemed equity receivers and denied capacity to sue. Id. at 121-22. See Note, 48 Harv. L. Rev. 835 (1935).

This decision resolved a conflict on the comparative legal rights of statutory and equity receivers. In Relfe v. Rundle, 103 U.S. 222 (1880), the Supreme Court held that statutory liquidators appointed to wind up insolvent corporations had standing to sue in place of the corporation. But in dictum the Court stated that by allowing the corporation to transact business within its jurisdiction, the state assented to all laws of the state appointing the receiver including those governing the administration of assets in liquidation. $I d$. at 22526. This led to a rule of law in many states allowing a foreign statutory receiver to recover before local attaching creditors as a matter of right. Cogliano v. Ferguson, 245 Mass. 364, 139 N.E. 527 (1923) ; Kinsler v. Casualty Co., 103 Neb. 382, 172 N.W. 33 (1919); Bockover v. Life Ass'n, 77 Va. 85 (1883). But Relfe v. Rundle was viewed differently by courts still desiring to favor local interests. A few held that the receiver's appointment by an equity court, even though ordered by statute, made him a chancery receiver instead of a statutory successor. Mieyr v. Federal Surety Co., 94 Mont. 508, 23 P.2d 959 (1933), rev'd sub nom. Clark v. Williard, supra. See Note, 48 Harv. L. Rev. 835 (1935). Other courts held title vested by statute without extraterritorial effect. Alwart Bros, Coal Co. v. Pittsburgh Fire Ins. Co., 253 Ill. App. 361 (1929) ; Gray v. Covert, 25 Ind. App. 561, 58 N.E. 731 (1900) ; Zacher v. Fidelity Trust and Safety Vault Co., 109 Ky. 441, 59 S.W. 493 (1900); see 3 Beale, Conflict of Laws $\S 560 A .4$ (1935). And others held they would favor local creditors over a foreign receiver irrespective of the latter's standing. Hieronymous Bros. v. China Mut. Ins. Co., 6 Ala. App. 97, 60 So. 452 (1912) ; Lackmann v. Supreme Council, 142 Cal. 22, 75 Pac. 583 (1904).

7. Clark v. Williard, 294 U.S. 211 (1935).

In the first Clark v. Williard decision, supra note 6, the Supreme Court refused to decide this issue. Refusal was based on the possibility that the state court's grant of precedence to local attachments was based on failure to construe correctly the status of the foreign liquidator. Id. at 122. On remand to determine the application of state law to the receiver as the holder of title to the corporation's assets, the state court interpreted state law as favoring local attachments. Mieyr v. Federal Surety Co., 97 Mont. 503, 34 P.2d 982 (1934). The Supreme Court affirmed, holding that although a receiver has title and thus must be recognized, the states have absolute power over disposition of property within their jurisdiction and may subordinate the receiver's claims to those arising under valid local attachments. Clark v. Williard II, supra at 213. For criticism of this decision, see Vance, supra note 1, at 343-44; GLeNN, Liguidation \$ 591 (1935); Note, 48 HaRv. L. REv. 835 (1935).

8. Van Schaick v. Parsons, 11 F. Supp. 654 (D. Mont. 1935) ; Hill v. Caldarera, 197 Ark. 659, 124 S.W.2d 825 (1939); Davis v. Amra Grotto, 169 Tenn. 564, 89 S.W.2d 754 (1936). The rule in these and other states that an attachment levied subsequent to the foreign statutory receiver's appointment takes precedence over the claims of the receiver is still in effect. See Annot., 98 A.L.R. 351, 374-75 (1935).

The ductrine of Clark 2 . Williard II, is not limited to those attachments obtained by lacal creditors. Local attachments are upheld even if obtained by foreign creditors. Indeed it would be unconstitutional for a state to give attachments by their own citizens greater effect than those of foreign citizens. See Blake v. McClung, 172 U.S. 239 (1898); 3 Beale, Conflict of LAws $\$ 560 \mathrm{~A} .2$ (1935). But a state could probably discriminate on the basis of residence. Thus it could refuse to recognize the attachments of a non-resident, whether or not a citizen of a foreign state. See Douglas v. New York, N.H. \& H.R.R., 
and size of local claims, regardless of what assets or claims may exist outside the state. ${ }^{9}$ On the other hand, states favoring ratable distribution of assets among all creditors, foreign or local, do not discriminate between the claims of foreign receivers and those of local creditors. ${ }^{10}$ Absent reciprocity, however, such a policy disfavors local claimants.

Past attempts to eliminate the inequitable distribution inevitably resulting from liquidation of insurance corporations with assets in states following these different policies have been unsuccessful. Both uniform state legislation and inclusion of insurance companies under the Federal Bankruptcy Act have been suggested as solutions to the problem.11 A Uniform Insurer's Liquidation Act, providing for partially ratable distribution of the insolvent's assets, was drafted in $1939 .{ }^{12}$ But the act has been adopted by only 16 states, and no

279 U.S. 377, 387 (1929) (limiting doctrine of Blake v. McClung) ; La Tourette v. McMaster, 248 U.S. 465 (1919).

Saving local assets for local claimants may be defended on the ground that one state should not be forced to accept the priorities and methods of distribution of another. $C f$. Clark v. Williard, 294 U.S. 211 (1935). This reasoning, if supporting current practices, would clearly not justify local favoritism under a uniform system of liquidation.

9. Comment, 36 Maro. L. Rev. 383, 389 (1953).

10. MeDonald v. Pacific States Life Ins. Co., 344 Mo. 1, 124 S.W.2d 1157 (1939) (discussing case law in the field) ; Martyne v. American Union Fire Ins. Co., 216 N.Y. 183, 110 N.E. 502 (1915) ; Pink v. Hanby, 220 N.C. 667, 18 S.E.2d 127 (1942). Some courts require the receiver to guarantee in some manner that local creditors will be given equal treatment with all other creditors when the assets are distributed. Buswell v. Order of the Iron Hall, 161 Mass. 224, 36 N.E. 1065 (1894) ; Engineering Co. v. Perryman Elec. Co., 113 N.J. Eq. 255, 166 Atl. 461 (Ch. 1933); Bockover v. Life Ass'n, 77 Va. 85 (18s3).

11. Appointing a federal equity receiver may be considered another solution. Under existing law, such a receiver will be appointed only if a federal question is presented or the requirements of diversity jurisdiction can be met. 7 Moore, Federal Practice If 66.06 (1956). However, once appointed, the federal receiver will be discharged if the Superintendent of Insurance in the insolvent's domiciliary state advises the appointing court that the state wishes to liquidate the insolvent. Refusal to continue the exercise of federal jurisdiction in such cases is based on the need for harmony in federal-state relationships. Penn Gen. Cas. Co. v. Pennsylvania ex rel. Schnader, 294 U.S. 189 (1935) ; $c f$. Pennsylvania v. Williams, 294 U.S. 176 (1935) (state controlled building and loan associations).

Moreover, the federal receiver will be able to hold ancillary proceedings only if the courts in the ancillary state have not first taken jurisdiction over local property. For the first court to gain constructive possession of the assets has exclusive jurisdiction over their administration. The federal receiver will be able to conduct ancillary proceedings only if the state court chooses to relinquish its jurisdiction. Penn Gen. Cas. Co. v. Pennsylvania ex rel. Schnader, supra; Lion Bonding \& Surety Co. v. Karatz, 262 U.S. 77 (1923). See also Harkin v. Brundage, 276 U.S. 36 (1928).

In the recent insolvency of the Inland Empire Insurance Co., the federal receiver has been able to marshal assets in sixteen of the twenty-one states in which Inland did business. In the other states, where jurisdiction over the insolvent's property was first assumed by the state courts, distribution will be made through independent receiverships. Brief for Receiver, p. 7, Inland Empire Ins. Co. v. Freed, 239 F.2d 289 (10th Cir. 1956). A system of multiple receiverships is highly undesirable. See note 49 infra and accompanying text. For a discussion of ancillary federal receiverships, see note $\mathbf{5 0}$ infra.

12. Reprinted in 9A UNIFORM LAws ANN. 151-59 (hereinafter cited as UILA). The National Conference of Commissioners on Uniform State Laws approved the Act in 1939. 
substantial prospects of future adoption are apparent. ${ }^{13}$ Furthermore, some adopting states made substantive changes limiting the act's uniformity. ${ }^{14} \mathrm{Non}-$ uniform as well as partially adopted, the UILA falls short of its goal. ${ }^{15}$ Moreover, Congress has steadfastly refused to consider an amendment making insurance companies subject to the Bankruptcy Act. ${ }^{16}$ Criticized as the result of insurance industry pressure against federal regulation, ${ }^{17}$ this refusal has been rationalized on the grounds that insurance corporations, like banks and other institutions greatly affected with the public interest, should not be allowed continued existence after insolvency through discharge in bankruptcy. ${ }^{18}$

Id. at 148. The UILA treatment of statutory deposits precludes a fully ratable distribution. See note 39 infra.

13. See 9A Unrform Laws Ann. 46 (Supp. 1956). Colorado, not listed in the table, also has enacted the UILA. Colo. Rev. Star. ANN. \$§ 72-18-1 to 12 (Supp. 1955).

In the first eleven years after its drafting (1939-1950), fourteen states adopted the UILA, among them the commercially significant states of Illinois, New York, Ohio and Massachusetts. In the last seven years only one state besides Colorado, New Mexico, has adopted the act. 9A Uniforar LAws ANn. 46 (Supp. 1956).

14. Illinois, for example, has made important changes in almost every section of the UILA. For a complete listing of statutory changes in all states, see the statutory motes following each section of UILA.

15. The UILA is based entirely on the notion of reciprocity among adopting states. $I d$. at 151-59. It can operate effectively only when followed by all states in which the insolvent did business. See Inland Empire Ins. Co. v. Freed, 239 F.2d 289, 293 (10th Cir. 1956) ; Martin v. General Am. Cas. Co., 226 La. 481, 76 So. 2d 537 (1954) (UILA provisions held not in force because one of the two states involved had not adopted the act). But sie Rosen v. Massachusetts Acc. Co., 282 N.Y. 447, 26 N.E.2d 972 (1940).

Even where no question of reciprocity under the UILA is involved, inequitable distribution is common. See Ace Grain Co. v. Rhode Island Ins. Co., 107 F. Supp. 80 (S.D. N.Y.), aff'd, $199 \mathrm{~F} .2 \mathrm{~d} 758$ (2d Cir. 1952) (resolution of procedural difficulties arising under narrow construction of UILA enabled equitable distribution, but at expense of costly litigation); note 39 supra. For a general discussion of the shortcomings of the UILA, see Bennett, stipra note 2, at 426.

16. See Vance, supra note 1 , at 355 (this solution "the only adequate and available remedy"); Van Schaick, supra note 1, at 227 (same); see also MOORE, BANKRUPTCY MANUAL 1104 n.9 (1939).

Congress, however, when devising relief for distressed railroad corporations, did not even consider the situation of insurance companies. Vance, supra note 1 , at 345.

17. Ibid. When the industry in this country was still in its infancy, and there was no widespread fear of federal control, insurance corporations could go through bankruptcy under the Bankruptcy Act of 1867. 14 Stat. 517, c. 176. See also Knickerbocker Ins. Co. v. Comstock, 83 U.S. (16 Wall.) 258 (1872).

18. 6 Ax. JUR., Bankruptcy $\S 114$ (1950). See also Brief for Receiver, p. 8, Inland Empire Ins. Co. v. Freed, 239 F.2d 289 (10th Cir. 1956). Banks, railroads, building and loan associations and municipal corporations are also excluded from bankruptcy. 30 STAт. 547 (1898), as amended, 11 U.S.C. \& 22(a) (1952). The Bankruptcy Act of 1898 originally excluded all corporations from voluntary bankruptcy, and only manufacturing, trading, printing, publishing and mercantile corporations could be made involuntary bankrupts. 30 Stat. 547. Congressional opposition to allowing voluntary bankruptcy to any rorporation was intense. 30 CoNG. REC. 787-90 (1897); 28 CoNG. REC. 4679-83 (1896). 
While this explanation is of dubious validity, it continues to have significant weight with Congress. ${ }^{19}$

Since uniform legislation and amendment to the Bankruptcy Act were last actively urged, a new possibility for curing the inequity of insurance liquiclations, direct federal regulation without resort to the Bankruptcy Act, has arisen. but Congress has not acted. In 1944 the Supreme Court reversed its long standing position and held insurance companies subject to federal regulation under the commerce power. ${ }^{20}$ However, Congress almost immediately passed the McCarran-Ferguson Act which, while placing the industry within the scope of the antitrust laws, the National Labor Relations Act and the Fair Labor Standards Act, left all other control over the industry to the states."1 Liquidation was included, doubtless because the problem of insolvencies had

Voluntary and involuntary bankruptcy were provided for most corporations by the 1910 amendment to the act. 36 STAT. 839 (1910). However, public service corporations rfmained excluded. Ibid.

Since insurance corporations are state regulated, it may be argued that insurance liquidations should also be a state function and thus not made subject to the Bankruptcy Act. However there seems to be no reason why regulation and liquidation cannot be separated. Other state regulated businesses, such as public utilities, are liquidated under the Bankruptcy Act. 1 Renrington, BankRuptcy $\$ 101$ (1950).

19. Inclusion under the Bankruptcy Act need not entail discharge and continued existence. The Constitution is silent on discharge in bankruptcy. U.S. CoNsT. art. I, \& \&, c1. 4. When the Constitution was ratified, bankruptcy was more for the benefit of creditors than debtors, and discharge was regarded with suspicion. The first Bankruptcy Act, Act of April 14, 1800, c. 19, 2 Stat. 19, did not contain a discharge provision as that term is understood today. 1 Collier, Bankruptcy If 0.04 (1956); 7 Remington, Bankruptcy $\$ \$ 2993-95$ (1955).

Nevertheless, the discharge provision has become so intertwined with the act as to appear inseparable from it. Id. $\$ 2996$. See also In re Warner-Quinlan Co., $17 \mathrm{~F}$. Supp. 659,665 (S.D.N.Y. 1936). This phenomenon may help to explain the policy against allowing public service corporations to go through bankruptcy despite the fact that a discharged corporation is in no economic position to resume business. GLENN, LIQUIDATION $\S 435$ (1935). The treatment of national banks illustrates Congress' unwillingness to grant discharges to public service corporations. See 19 STat. 63 (1876), 12 U.S.C. $\$ \$ 191,197$ (1952) ; Rev. Stat. $\S \S 5234-38$ (1875), 12 U.S.C. $\$ \$ 192-96$ (1952) ; 48 Stat. 193 (1933), 12 U.S.C. $\$ 197$ (a) (1.952); 24 STAT. 8 (1886), 12 U.S.C. $\$ \$ 198-200$ (1952). National banks are liquidated, but not discharged, under these special provisions of the Banking Act.

20. United States v. Southeastern Underwriters Ass'n, 322 U.S. 533 (1944). This decision in effect overruled a series of earlier cases holding insurance not to be in interstate commerce and hence not subject to direct federal control. See, e.g., Paul v. Virginia, 75 U.S. (8 Wall.) 168 (1868) ; cases collected in United States v. Southeastern Underwriters Ass'n, supra at 567.

21. 59 STAT. 33 (1945), 15 U.S.C. $\$ \S 1011-15$ (1952). Industry pressure was influential in causing passage of the act. See, e.g., Harrington, An Exploration of the Effects of the SEUA Decision, 261 INs. L.J. 590, 592 (1944). Two attacks on the constitutionality of the act have failed. Prudential Ins. Co. v. Benjamin, 328 U.S. 408 (1946) (Congress may allow the states to continue taxing interstate insurance corporations); Robertson v. California, 328 U.S. 440 (1946) (Congress may allow the states to continue regulating interstate insurance corporations). 
virtually disappeared with the end of the depression. ${ }^{22}$ The current wave of insurance insolvencies, demonstrating reappearance of the problem, accentuates the continued inability of the states to meet its demands ${ }^{23}$ and revitalizes the congressional opinion expressed in considering the McCarran-Ferguson Act that federal regulation would be forthcoming if state control proved inadequate. ${ }^{24}$

Federal regulation under the commerce power, through amendment to the McCarran-Ferguson Act, could achieve equitable distribution of insurance company assets. ${ }^{25}$ The amendment should provide for appointment of a disinterested federal receiver, experienced in the field of insurance, with the power to marshal assets, wherever located. ${ }^{26}$ The receiver would be appointed by the federal district court in the state of incorporation or the jurisdiction in which the principal offices of the company are located. ${ }^{27}$ The domiciliary state's

22. See Comment, 36 Maro. L. Rev. 383, 384 (1953). No statistics on the exact number of insurance insolvencies are available. Letter from Dun \& Bradstreet, Inc. to the Yale Law Journal, May 6, 1957, on file in Yale Law Library. However statistics on insolvencies in related fields show a startling change between 1940 and 1945, when the MeCarran-Ferguson Act was passed. Over 24,000 bank failures occurred between 1921 and 1940. From 1941 to 1946 only 22 failures took place. U.S. Bureau of the Census, Statistical Abstract of the United States: 1956, table no. 514. See also id. table no. 532 (savings and loan association failures).

23. The wave of insolvencies started with the liquidation of the Preferred Accident Insurance Co. of New York in April, 1951. At the date of the liquidation petition Preferred was doing business in 46 states. See Bennett, supra note 2 , at 424 . Within the past three years, over forty Texas insurance companies have collapsed, the biggest failure coming in February, 1957 when the Insurance Company of Texas was reported to be hopelessly insolvent. Time, Feb. 18, 1957, p. 92.

The continued inadequacy of state liquidation is particularly evident in Inland Empire Ins. Co. v. Freed, 239 F.2d 289 (10th Cir. 1956). When Inland was declared insolvent, the Idaho Superintendent of Insurance was required by statute to liquidate the company. Admitting his inability to do so under the existing state procedure, he requested the court to appoint a federal receiver. Brief for Receiver, p. 10, Inland Empire Ins. Co. v. Freed, supra. For discussion of federal receiverships, see note 11 supra.

24. See 91 Cong. Rec. 479, 481, 483, 485, 1478, 1481, 1483, 1486, 1488 (1945). See also MicCarran, Federal Control of Insurance: Moratorium Under Public Law 15 Expired July 1, 34 A.B.A.J. 539, 540 (1948) ; McCarran, Insurance as Commerce-After Four Years, 23 Notre Dame Law. 299, 307 (1948).

25. Dealing with insolvencies through the commerce rather than the bankruptcy power is supported by recent precedent. Railroad reorganizations, though nominally still under $\S 77$ of the Bankruptcy Act, 47 Stat. 1474 (1933), 11 U.S.C. $\$ 205$ (1952), are now handled almost exclusively by the ICC acting under an express amendment to the Interstate Commerce Act. 62 STAT. 163 (1948), 49 U.S.C. $\$ 20$ (b) (1.952). See Polatsek, The IVreck of the Old 77, 34 CORNELL L.Q. 532 (1949).

26. Since under the proposed amendment, the receiver's appointment would be required by federal law, no jurisdictional problem would be presented in securing his appointment by a federal court. See U.S. Const. art. III, \& 2, cl. 1. See also Moore, Coaraientary on the U.S. Juntctal Code $\{0.03$ (22) (1949); Moore, Federal Practice $\pi 66.06$ (1956).

27. "The principal place of business or the place where the principal assets are located is a proper district for the institution of the primary receivership." 7 MOORE, FEDERAL Practice $\llbracket 66.06$ (1956). Cf. Saltz v. Saltz Bros., 84 F.2d 246 (D.C. Cir. 1936). Appoint- 
Superintendent of Insurance, the Superintendent of Insurance of any other state where the company does business or the holder of an unsatisfied judgment would be entitled to petition for such appointment. ${ }^{28}$ Upon determining the petition's validity, the court would dissolve the corporation and vest title to its assets in the receiver who would then be recognized in all federal district courts. ${ }^{29}$ And by invalidating judicial liens secured during the company's insolvency and within a certain period prior to the date the petition was filed. the amendment could prevent local creditors from so obtaining more than their ratable share of the company's assets. ${ }^{30}$

Completely ratable distribution, however, cannot be achieved without modifying the existing system of statutory deposits. ${ }^{31}$ These deposits comprise fixed

ing the primary receiver in the district of the insolvent's principal office (where the company directors have their offices and where the bulk of the books and records are located) allows the receiver at once to take over a large part of the firm's assets as well as most of its books and records. It prevents tampering with the books and saves the expense of having to collect them. Brief for Receiver, p. 6, Inland Empire Ins. Co. v. Freed, 239 F.2d 289 (10th Cir. 1956).

28. Allowing the domiciliary state Superintendent of Insurance to petition for appointment of a primary receiver is in line with current state practice. See, e.g., N.Y. INs. LAw $\S 511$; VA. Code ANN. $\$ 38.1-131$ (Supp. 1956). Petition by a non-domiciliary Insurance Superintendent, however, departs from such practice. But since he is likely to be aware of the company's general financial position through knowledge of its local status, allowing the non-domiciliary Insurance Superintendent to initiate proceedings seems a sound provision.

Originally only a judgment creditor could petition for the appointment of a federal receiver. Harkin v. Brundage, 276 U.S. 36, 52 (1928) ; Pusey \& Jones Co. v. Hanssen, 261 U.S. 491,497 (1923). Erie R.R. v. Tompkins, 304 U.S. 64 (1938), requiring federal courts to follow state substantive law in cases of diversity jurisdiction, has raised doubt as to the status of Pusey \& Jones Co. v. Hanssen, supra. FED. R. Crv. P. 18(b) also casts doubt on the Pusey doctrine. 7 Moore, Federal Practice $\llbracket 66.05$ (1) (1956). See Inland Empire Ins. Co. v. Freed, 239 F.2d 289 (10th Cir. 1956). Since the appointment of a federal receiver would not be based on diversity jurisdiction, see note 26 supra, Congress would not be bound by Erie R.R. v. Tompkins.

29. There are a number of grounds for liquidating an insurance corporation. A typical list may be found in the N.Y. INS. LAw $\$ 511$.

Dissolving the company would eliminate conflict on who holds title to specific assets, the primary receiver or an ancillary receiver appointed to conserve those particular asscts, by making the primary receiver's title clear. See UILA, Commissioner's Prefatory Note No. 3.

Federal receivers are presently recognized in all district courts. 62 STat. 922 (1948), 28 U.S.C. $\$ 754$ (1952) ; see note 50 infra.

30. The suggestion follows the pattern of the Bankruptcy Act, 30 Srat. 564 (1898), as amended, 11 U.S.C. $\$ 107$ (a) (1) (1952). The four month period there provided also appears in UILA $\S 9$. Creditors whose liens are so invalidated should be allowed to file unsecured claims against the insolvent. Ross v. American Employers' Liab. Ins. Co., 56 N.J. Eq. 41, 38 Atl. 22 (Ch. 1897) ; In the Matter of Empire State Surety Co., 214 N.Y. 553, 108 N.E. 825 (1915). See Morris v. Jones, 329 U.S. 545 (1947) ; cf. Bankruptcy Act $\S 57(\mathrm{~g}), 30$ STat. 560 (1898), as amended, 11 U.S.C. $\$ 93(\mathrm{~g})$ (1952).

31. The problems of statutory deposits and marshalling of assets are inseparable because such deposits usually form a good part of the insolvent's assets in foreign jurisdictions. See Brief for Appellee, p. 16, Inland Empire Ins. Co. v. Freed, 239 F.2d 289 (10th Cir. 1956). 
amounts of cash or securities left in trust with a designated state official. Insurance companies must, in most states, post such a deposit as a prerequisite to obtaining a corporate charter ${ }^{32}$ Many states also require foreign insurance corporations to meet smaller deposit requirements before being admitted to do business in the state. ${ }^{33}$ Deposits by foreign corporations fall into two categories, general and special, with most states requiring both types. ${ }^{34} \mathrm{~A}$ general deposit is designed to protect all policyholders in the United States from the insurance company's subsequent insolvency. ${ }^{35}$ A special deposit, on the other hand, is available only to local policyholders and creditors. ${ }^{36}$ By definition, then, special deposits place substantial barriers in the way of fully ratable distribution. ${ }^{37}$ And since special deposits are generally administered and distributed by independent state-appointed receivers, ${ }^{38}$ they cause an uncoordi-

32. See, e.g., Ill. ANn. Stat. c. 73, § 638 (Smith-Hurd Supp. 1956) ; LA. Rev. Stat. Ann. $\$ 22.36$ (Supp. 1956); Mo. Ann. Stat. $\$ 376.290$ (Supp. 1956). A deposit by a domestic insurance company is regarded in most states as a trust fund for the benefit of all policyholders and creditors, wherever resident. 19 APPLEMAN, INSURANCE LAW AND Practice $\$ 10488$ (1946). See McMurray v. Commonwealth, 249 Mass. 574, 144 N.E. 718 (1924). The deposit will be surrendered to the primary receiver or the court when the company is declared insolvent. See Hobbs v. Occidental Life Ins. Co., 87 F.2d 380, 384 (10th Cir. 1937). Many states accept a surety bond in lieu of cash or security deposit. See, c.g., Tex. Ins. Code Ans. art. 6.09 (Supp. 1956) ; VA. Code Ans. \$ 38.1-108 (Supp. 1956).

33. For the deposits required of foreign and alien surety and casualty insurance companies by every state and territory, see Assoctation of Casualty and Surety Companies, Multiple Line Underwriting (1950).

34. Ibid.

35. Creditors are usually not beneficiaries of these statutory deposit trusts. Cf. American United Life Ins. Co. v. Fischer, 130 F.2d 643 (8th Cir. 1942). See also 19 Appleatan, Insurance Law and Practice $\$ 11096$ (1946). But see Maine Rev. Stat. ANN. c. $60, \S 50$ (1954) (creditors share on a par with policyholders).

36. See Association of Casualty and Surety Companies, Multiple Line UnderWRITING (1950). Usually both classes share on a par. Virginia, however, gives local policyholders some preference over local creditors. VA. CoDE ANN. § 38.1-110 (Supp. 1956).

37. Bennett, supra note 2 , at $426-27$.

Ratable distribution has also been precluded by judicial interpretation of deposit laws. Thus, in Ohio, a general deposit was turned into a special deposit by court decision. The Ohio statute had originally provided that the beneficiaries of the statutory deposit trust be resident policyholders. Act of April 24, 1873, 70 OHo LAws 152. By amendment the legislature changed the beneficiaries to all policyholders of the company. Act of April 15, 1904, 97 Оніо Laws 154. The court held the legislature still intended the deposit to be held for the benefit of Ohio policyholders. State $e x$ rel. Turner v. Union Cas. Ins. Co., 8 Ohio App. 285, 292 (1917). The current Ohio statute, OHIo Rev. Cone ANN. § 3929.07 (Page Supp. 1956), provides that beneficiaries shall be all policyholders and is still construed as being only for the benefit of Ohio policyholders. State $e x$ rel. Bohlinger v. Annat, 68 Ohio L. Abs. 453, 123 N.E.2d 71 (C.P. 1954).

38. Hankins v. Sallard, 188 So. 411 (La. App. 1939) ; Phillips v. Perue, 111 Tex. 112, 229 S.W. $\$ 49$ (1921). See also Cooke v. Warner, 56 Conn. 234, 14 Atl. 798 (1888). But see Holloway v. Federal Reserve Life Ins. Co., 21 F. Supp. 516 (W.D. Mo. 1937) (when the insolvent's obligations have been completely reinsured, reinsurer obtains deposit without need of local receiver). The fund is generally held by the State Treasurer and dis- 
nated distribution as well as the unnecessary additional expense of multiple administration. $^{39}$ Thus, unlike general deposits which may be justified as providing needed protection for all policyholders, ${ }^{40}$ special deposits hinder the basic aims of insolvency proceedings by favoring local interests and increasing the expense of liquidation. ${ }^{41}$

A federal law creating a uniform system of state statutory deposits would provide the necessary protection to policyholders without precluding ratable distribution or impairing the efficiency of insolvency proceedings. ${ }^{42}$ An intra-

tributed by the State Superintendent of Insurance or a private receiver. $C$ f. Continental Bank and Trust Co. v. Apodaca, 239 F.2d 295, 296 (10th Cir. 1956). The primary receiver does not take control of these deposits because they are not considered part of the general assets of the insolvent, but a trust fund for the benefit of the beneficiaries designated by statute. Blake v. McClung, 172 U.S. 239, 257 (1898) ; Boston \& A.R.R. v. Mercantile Trust and Deposit Co., 82 Md. 535, 34 Atl. 778 (1896); In re New Jersey Fidelity and Plate Glass Ins. Co., 15 N.J. Misc. 384, 191. Atl. 475 (Ch. 1937); Phillips v. Perue, supra; Glenn, Liquidation $\$ 599$; Vance, supra note 1 , at 351 . To the same effect is Continental Bank and Trust Co. v. Gold, 140 F. Supp. 252 (E.D.N.C. 1956). But sce Continent Bank and Trust Co. v. Apodaca, supra (statutory deposit a general asset of the insolvent).

39. Since the domicilary receiver is supposed to distribute the assets of the company on a ratable basis, creditors and policyholders who have realized part of their claims out of a special deposit are not entitled to share in the distribution until other policyholders and creditors have received an equal percentage of their claim. American Bonding \& Cas. Co. v. Chicago Bonding \& Ins. Co., 251 Ill. App. 549 (1929). See also 2 Beale, Conflict of LAws $\$ 264.4$ (1935). Contra Matter of People (Southern Surety Co.), 282 N.Y. 54, 24 N.E.2d 845 (1939) (overruled by N.Y. INs. Law \$ 545.2). The domiciliary liquidator must coordinate his distribution with that made out of every special deposit fund, a procedure entailing additional administration costs. See Patrerson, Essentisls of InsurANCE LAW 19 (1935); Bennett, supra note 2, at 426-27.

UILA, even if fully adopted, would not solve this problem for it accepts the state statutory deposit system. UILA $\$ 7$.

40. See note 35 supra.

41. The insurance industry itself disfavors special deposit laws. For they disperse the insurance company's assets throughout the country and thereby place artificial restrictions on the corporation's ability to handle its investment portfolio. Letter from Robert N. Gilmore, Jr., Associate Counsel, Association of Casualty and Surety Companies, to the Yale Law Journal, April 16, 1957, on file in Yale Law Library. The industry's objection does not extend to general deposits because many states now instead accept a certificate issued by any other state that the required amount, there on deposit, is held for the benefit of all policyholders of the company. See, e.g., VA. Code ANN. $\$ 38.1-113$ (Supp. 1956); WasH. Rev. Code Anv. $\$ 48.05 .080(2)$ (1951). The deposit is usually made in the corporation's domiciliary state which issues the required certificate. Some state statutes provide for voluntary deposits and issuance of the required certificates so that domiciliary corporations can comply with the deposit requirements of foreign states. See N.Y. INS. Law \$ $100 ;$ Pa. Stat. Ann. tit. 40, \$181 (Purdon Supp. 1956).

42. An analogous system handling deposits by face-amount certificate companies is currently utilized. 54 STAT. $835(1940)$, 11 U.S.C. $\$ 107(f)$ (1952). The system recognizes the importance of state deposits but eliminates multiple administration by giving power over their disposition to the trustee in bankruptcy. See Collier, Bankruptcy ปा $67.50,67.53$ (1956). 
state insurance company would, of course, continue to be subject to the statutory deposit requirements of its own state. Upon qualifying to do business in other states, however, the company would become subject to a federal law requiring an additional fixed basic deposit with the state treasurer of its domiciliary state. ${ }^{43}$ This deposit would be increased by further deposits each time the firm was admitted to do business in a new state, 44 with the size of the main and subsidiary deposits based on current state practice. ${ }^{45}$ In case of insolvency, the fund wotld be administered by the primary receiver handling the general assets of the firm. ${ }^{46}$ The beneficiaries of this fund would, consistent with the theory of general deposits, be all United States policyholders of the corporation. While so retaining the main substantive provisions of existing state law, this system of statutory deposits would eliminate the multiple administration of assets and favoritism toward local interests inherent in special deposits. Its use in the proposed amendment to the McCarran-Ferguson Act would, therefore, assure the achievement of ratable distribution and facilitate resolution of the major problems that have plagued insurance liquidations. ${ }^{47}$

The proposed amendment has the further advantage of enabling more persons to prove their claims, a recurrent, though secondary, problem in insurance liquidations. Currently, small claims are often dropped when local assets are insufficient to pay the cost of a local ancillary receivership proceeding, and the cost of proving such claims in a distant state is greater than their expected realization. ${ }^{48}$ Under the existing system, the domiciliary receiver generally cannot hold proceedings outside the state of his appointment. Hence, proceedings will be held elsewhere only on the appointment of an ancillary receiver,

43. All states require foreign insurance corporations to comply with certain requirements before admitting them to do business. See, e.g., S.C. CoDE $\$ 37.107$ (Supp. 1956). See also 29 Am. Jur., Insurance $\$ 34$ (1940). Thus, the determination that a company has qualified to do business in another state can be easily made.

44. Concentration of all statutory deposits in one state should overcome the insurance industry's objection to special statutory deposits. See note 41 supra.

45. The deposit requirements should vary, as under the present system, depending on the type of insurance the firm writes. See Assoctation of Casualty and SuRety Conlanies, Multiple Line Underwiting (1950). Thus, a burial or title insurance comjany would not have to make as large a deposit as a life or casualty company because of the difference in number and size of claims normally filed upon insolvency.

The proposed amendment should, in accord with current practice, include a provision allowing the corporation to substitute securities in the deposit fund, thus increasing the corporation's ability to manipulate its investments. See, e.g., Iowa CodE ANN. $\$ 511.8(13)$ (Supp. 1956) ; N.Y. Ins. LAw $\$ 98(5)$.

46. See note 38 supra.

47. The amendment should include a provision for secured claims. A secured creditor should be allowed to waive his security and file as an unsecured creditor or to realize on the security and file an unsecured claim for any balance. See UILA, \& 8. See, generally, GlenN, Liguidation c. 36 (1935).

48. Comment, 36 MIARg. L. Rev. 383, 386 (1953). Cf. UILA, Commissioner's Prefatory Note No. 4. 
a costly and unnecessary procedure. ${ }^{49}$ On the other hand, the federal receiver contemplated by the proposed amendment must be recognized in any district court. ${ }^{50} \mathrm{He}$ can therefore hold ancillary proceedings himself if this should prove less expensive than the appointment of a local representative. ${ }^{\text {II }}$ Small claims would thus not have to be abandoned, and the general depletion of the insolvent's assets in administrative costs would be reduced.

While achieving ratable distribution and minimizing costs, federal liquidation of insurance corporations would have to meet the question of claim priorities. A provision for claim priorities like that of the Bankruptcy Act might dispose of the difficulties. ${ }^{52}$ Although such a solution has the advantage of simplicity, it necessarily overlooks valid policy differences among the states. ${ }^{\text {t3 }}$

49. Comment, 36 MARQ. L. Rev. 383, 387 (1953). The usual requirement is that the State Superintendent of Insurance or a private party be appointed as ancillary receiver for an insolvent foreign insurance company. See, e.g., FLA. Stat. ANn. $\$ 626.12$ (Supp. 1956); UILA \$ 3. See also Lion Bonding \& Surety Co. v. Karatz, 262 U.S. 77, 87 (1923); GOODRICH, CONFLICT OF LAWS § 202 (1949).

Some states require the appointment of a private, compensated receiver. See, e.g., Tex. Ins. Code Ans. art. 21.28, § 13 (Supp. 1956); W. VA. Code ANn. § 3353 (1955). In many states, however, the receiver is not specially compensated since he is the state Superintendent of Insurance. See, e.g., Iowa CoDE ANN. \$ 505.9 (Supp. 1956); UILA $\$ 3(1)$. It may be argued that a federal receivership would be more costly because of the additional salary. See Comment, 36 MARQ. L. REv. 383, 390 (1953). However, overall administration cost is reduced by a centralized federal receivership. See Brief for Receiver, p. 7, Inland Empire Ins. Co. v. Freed, 239 F.2d 289 (10th Cir. 1956).

50. 62 STAт. 922 (1948), 28 U.S.C. $\$ 754$ (1952). Prior to 1948, the Judicial Code provided that a federal receiver had standing only in the district courts within the judicial circuit of the appointing district court and then only with regard to fixed property. 36 STAT. 1102 (1911). Thus where fixed property was involved, ancillary appointment was necessary only in districts outside the judicial circuit of the appointing court. 7 Moore, FEDERAL PRACTICE If 66.08 (1956). But insurance company assets were not considered fixed property. Lion Bonding \& Surety Co. v. Karatz, 262 U.S. 77, 87 (1923). Until 194S, therefore, a federal equity receiver for an insurance company had to obtain an ancillary receivership in every district in which the insolvent's assets were located, whether within or without the judicial circuit. 7 Moore, Federal Practice supra. The 1948 revision resolved the problem by extending federal receivership to all property, fixed or not, and by giving the receiver capacity to sue in any district court without ancillary appointment. 62 Stat. 922 (1948), 28 U.S.C. $\$ 754$ (1952). See also Revisor's Note following 28 U.S. C.A. $\S 754$ (Supp. 1956).

51. The primary receiver should have discretion to determine the need for appointing an ancillary receiver. However, Congress should make ancillary proceedings mandatory where a given number of creditors, desiring to prove claims, petition for such proceedings in their jurisdiction. UILA $\S 3$, for example, requires ancillary proceedings to be held on petition of ten or more creditors. If less than the required number of creditors petition, proceedings should be at the discretion of the primary receiver.

52. Bankruptcy Act $\$ 64,30$ Stat. 563 (1898), as amended, 11 U.S.C. $\$ 104$ (1952).

53. See, e.g., Mass. ANn. Laws c. $175, \S 46$ (Supp. 1956) (unreimbursed policyholder losses receive priority over claims for unearned premiums on cancelled or unexpired policies); Kelsey v. Cogswell, 112 Fed. 599, 606 (C.C.N.D. Ga. 1901) (same construction given Georgia statute).

Claims of injured workmen are given varying degrees of priority over claims of other policyholders and creditors. See, e.g., CaL. LAB. Code ANN. $\$ 4908$ (Deering Supp. 1955); 
These differences could be recognized, and a degree of uniformity effected, by giving priority to the claims preferred in all states-state taxes, wages, debts and taxes due the United States and administration expenses-while leaving subsequent priorities to state discretion. ${ }^{54}$ Thus assets remaining after distribution in accordance with the federal priorities would be allocated to each state in the proportion that the claims of its residents bear to the total amount of claims filed. The assets so allocated would then be distributed by the federal receiver according to the individual state priority laws. ${ }^{55}$ In giving effect to the valid policy differences among the states, this system of priorities should temper the traditional reluctance of Congress to dictate to the states in the field of insurance.

Fla. Stat. Ann. $\$ 440.23$ (Supp. 1956); Mass. Ann. LAws c. 175, § 46A (Supp. 1956); N.Y. WORKMEN's CoMr. LAW $\$ 34$. The theory is that an injured workman is least able to bear the hardships created by the insurer's insolvency. Van Schaick, Should Insolvent Insurance Companies be Administered in Bankruptcy?, A2 CoRporate ReoRganizations 227,228 (1939). But this hardship will arise only if the workman is subsequently unable to collect from his employer since the insolvency of the insurer cannot relieve the employer from liability for the injury. American Fuel Co. v. Industrial Comm., 55 Utah 483, 187 Pac. 633 (1920). Therefore, in many cases the effect of this priority will be to protect the employer rather than the employee.

If workmen's compensation claims are to be given priority, Congress should treat them in the same manner as wages, taxes, debts due the United States and administrative expenses. See note 54 infra. For it appears inequitable to allow injured workmen in one state to collect their claims in full while those in another state receive only a small percentage. See Vance, Interstate Aspects of the Liquidation of Insolvent Insurance Corporations, 6 Association of Life Insurance Counsel Proceedings 343, 352-53 (1935). Under the UILA the priority system of the state of incorporation is controlling. UILA $\S 6$. Thus, either all workmen's compensation claims will have priority or none will, the result depending on the entirely fortuitous circumstance of the insolvent's choice of domicile. The law of the jurisdiction where the accident took place is irrelevant. See UILA, Commissioner's Prefatory Note No. 5.

54. See, e.g., Cal. Ins. Code ANv. $\S 1033$ (Deering Supp. 1955); Cal. Lab. Code ANn. $\S 100.5$ (Deering Supp. 1955). See also GLENN, Liquidation $\$ \S 513,514,518,555$ (1935) (state taxes, debts due the United States, wages and administrative expenses respectively). Under present law, debts due the United States have first priority in insolvency proceeding not under the Bankruptcy Act. Rev. STAT. \$ 3466 (1875), 31 U.S.C. § 191 (1952). See Kennebec Box Co. v. O. S. Richards Corp., 5 F.2d 951 (2d Cir. 1925) (administration expenses, although not specifically mentioned in the statute, to be paid first). Under the Eankruptcy Act, debts due the United States have fifth priority. 30 STAт. 563 (1898), as amended, 11 U.S.C. $\$ 104$ (a) (5) (1952). Section 3466 priorities have been the subject of severe criticism. See, e.g., Kennedy, The Relative Priority of the Federal Government: The Pernicions Career of the Inchoate and General Lien, 63 YaLe L.J. 905 (1954). In enacting the proposed amendment to the McCarran-Ferguson Act, therefore, Congress may be well advised to give debts due the United States the same priority as given by the Bankruptcy Act.

55. Thus, assume that after payment of administration expenses, taxes, wages and debts due the United States, $\$ 100,000$ in assets remain and $\$ 500,000$ in claims must still be satisfied. Of these claims $\$ 50,000(10 \%)$ were filed by creditors residing in State X. $10 \%$ of the $\$ 100,000$, or $\$ 10,000$, would therefore go to creditors in State X. The federal receiver would distribute this $\$ 10,000$ in accordance with the priority laws of State X. 
Moreover, the proposed amendment to the McCarran-Ferguson Act will result in an equitable and uniform distribution without jeopardizing state control of insurance or congressional policy against allowing insurance companies to go through bankruptcy. The amendment would operate entirely within the framework of state regulation and the existing court system. No new federal agency would be necessary, and the federal government would not incur any additional expense. ${ }^{56}$ The only major change would be the elimination of state policy favoring local interests, since postponement of the receiver's claims could no longer be effected, and special deposits would be non-existent. ${ }^{57}$ Use of initial federal priorities will, of course, provide a measure of uniformity in the distribution of the insolvent corporation's assets. And recognition of subsequent state priorities does not depart from the aim of equitable distribution. While the order in which their claims will be paid remains a matter of individual state policy, creditors and policyholders of all states can expect satisfaction measured by their proportional representation of the total claims rather than a fortuitous location of assets.

56. The receiver's fee would be paid out of the insolvent's assets, not government funds. See GLENN, LiQuidation \$ 555 (1935).

57. See text at notes $28-29,46-47$ supra.

The public interest may be better served by federal regulation of insurance not confined to liquidation. For example, the FTC has asserted jurisdiction over certain insurance mail advertising practices following state failure to regulate that phase of the industry effectively. American Hospital and Life Ins. Co., 3 CCH Trade Reg. Rep. $\llbracket 25954$ (FTC 1956), petition for revieze filed, $3 \mathrm{CCH}$ TRADE REG. REP. I 26114. Cf. United States v. Sylvanus, 192 F.2d 96 (7th Cir. 1951). See also Business Week, May 25, 1956, p. 152. Recent developments in Texas demonstrate the need for further federal regulation. The Insurance Department of that state has been accused of extensive corruption. Harpers, March, 1957, p. 68. And over forty Texas insurance companies have become insolvent in the past three years. Time, Feb. 18, 1957, p. 92. 